\title{
New Record of Two Xanthid Crabs (Crustacea: Decapoda: Xanthidae) from Korea
}

\author{
Sang-kyu Lee, Hyun Soo Rho, Dongsung Kim* \\ East Sea Research Institute, Korea Institute of Ocean Science \& Technology, \\ Uljin 767-813, Korea
}

\begin{abstract}
Xanthid crabs, decapod crustacean, with the black coloured fingers, are easily found under rocks or stones in the intertidal or subtidal zones. Two xanthids, Etisus laevimanus Randall, 1840 and Paraxanthias elegans (Stimpson, 1858), were newly reported in Korean waters as part of continuous taxonomic studies on crabs. The genus Paraxanthias Odhner, 1925 was also reported for the first time in Korea. Of these, the examined specimen of $P$. elegans showed eight feathery hairs on the subdistal tip of the first gonopod, which differs from the description of Dai and Yang at 1991. Here, the descriptions and illustrations of these species are provided. Korean Xanthoidea currently consists of 30 species belonging to 25 genera.
\end{abstract}

Keywords: new report, Paraxanthias elegans, Etisus laevimanus, Decapoda, Korean fauna

\section{NTRODUCTI ON}

Many members of the family Xanthidae MacLeay, 1838, with the black coloured fingers, occur in the Indo-West Pacific. They are easily found around the intertidal or subtidal zones, and hide under the rocks or in the sponges and other sessile invertebrates, and graze on alge or on detritus.

Until now, 28 species of 24 genera belonging to the family Xanthidae have been recorded among Korean fauna (Lee et al., 2012). As a result of continuous taxonomic studies on Korean crabs, two xanthid crabs, Etisus laevimanus Randall, 1840 and Paraxanthias elegans (Stimpson, 1858), were newly reported from Korean waters. In Korea, Etisus anaglyptus H. Milne Edwards, 1834 was reported only in the genus Etisus H. Milne Edwards, 1834, and the genus Paraxanthias Odhner, 1925 was reported for the first time. With this report, Korean xanthoid crabs are now composed of 30 species in 25 genera. We provide their morphological descriptions are provided with illustration, in the current report.

\section{MATERI ALS AND METHODS}

Materials examined in this study were preserved in $95 \%$ ethyl alcohol, and deposited in the Marine Arthropod Depository
Bank of Korea (MADBK), Seoul National University. The specimens were observed under a microscope (Model M165C; Leica, Wetzlar, Germany). Drawings were made with the aid of camera lucida. Images were recorded using Digtal camera (Model Nikon D800; Nikon Imaging Korea Co., Ltd., Korea), and developed with the software (Model Helicon Focus; Helicon Soft Ltd., Kharkov, Ukraine).

The abbreviation "cl" and "cw" referred to the carapace length from the front to the posterior dorsal margin of the carapace and to the width of the carapace measured at the wides part, respectively. The zones of the carapace $(1-3 \mathrm{M}, 1 \mathrm{~F}, 2 \mathrm{~F}$, $1-4 \mathrm{~L}$, and $2 \mathrm{P})$ were divided according to Dana (1853) and Serène (1984). The classification followed that of $\mathrm{Ng}$ et al. (2008).

\section{SYSTEMATIC ACCOUNTS}

Order Decapoda Latreille, 1802

Family Xanthidae MacLeay, 1838

Genus Etisus H. Milne Edwards, 1834

${ }^{1 *}$ Etisus laevimanus Randall, 1840 (Figs. 1-3)

Etisus laevimanus Randall, 1840: 115; Forest and Guinot, 1961: 88; Sakai, 1976: 455, fig. 245, Pl. 161, fig. 1; Dai

(C) This is an Open Access article distributed under the terms of the Creative Commons Attribution Non-Commercial License (http://creativecommons.org/ licenses/by-nc/3.0/) which permits unrestricted non-commercial use, distribution, and reproduction in any medium, provided the original work is properly cited.

pISSN 2234-6953 eISSN 2234-8190

*To whom correspondence should be addressed

Tel: 82-54-780-5301, Fax: 82-54-780-5319

E-mail: dskim@kiost.ac 
and Yang, 1991: 324, fig. 164B(5), Pl. 42(2).

Etisus convexus Stimpson, 1858: 31; 1907: 36, Pl. 5, fig. 2.

Etisus (Etisus) laevimanus: Holthuis, 1953: 21.

Material examined. Korea: 1 శூ (cl $28.3 \mathrm{~mm}$, cw $44.8 \mathrm{~mm})$, 1 우 (cl $19 \mathrm{~mm}, \mathrm{cw} 28.6 \mathrm{~mm}$ ), Gyeongsangbuk-do, Uljin-gun, Jukbyeon-myeon, Hujeong-ri, 27 Sep 2012, SCUBA diving, Col. Rho HS.

Description. Carapace (Fig. 1A) outline distinctly rounded, subcircular; surface convex, smooth and punctuated; regions recognizable, gloves separating regions shallow, but those surrounding gastric regions deeper; 5L with a deep depression on its anterior border; gastric-cardiac region $\mathrm{H}$-shaped, and deep groove. Front (Figs. 1A, B, 2B) produced, subquadrate, distinctly truncate, anterior margins bearing strong granules, divided into 2 lobes; each lobe with anterior margin slightly slanting, concave and separated from orbit by wide V-shaped notch. Dorsal margin of orbit (Figs. 1A, B, 2B) with one fissure. Anterolateral border (Figs. 1A, 2B) bearing 5 distinct teeth, including triangular postorbital angle as first; first 2 teeth flat and obtuse; last 2 dentiform but claw-shaped. Antennules folded obliquely. Basal article of antenna not reaching margin of carapace front, strong lateral flange greatly exceeding articulation with flagellum, abutting inner suborbital lobe blocking orbital hiatus, flagellum centered on broad antennal sulcus, excluded from orbit. Third maxillipeds (Fig. 3A) with merus produced at outer-distal angle.

Chelipeds (Figs. 1A, 2A, C, D) massive, robust, unequal. Chelipeds about 2.5 times as long as carapace length. Carpus with an obtuse tooth at the inner angle. Propodus depressed, subequal to finger in length; immovable finger with 1 obtuse tooth at sub tip. Dactylus of major chela depressed, with 2 obtuse teeth on inner margin. Fingers dark brown and pigment extended into proposes.

Ambulatory legs (Fig. 1A) short, heavy, moderately setose, shorter than carapace length; upper and lower border with hairs; anterior and posterior surfaces naked. Dactylus proximally bearing small, slightly elevated condyle abutting locking arch on distal margin of propodus, distally terminating in elongated corneous tip.

Male abdomen (Fig. 3B) narrow, elongated; third to fifth somites fused, lateral lobes of fused third somite weakly sculptured, granular, somite suture limited to slight indentations in lateral margin; sixth segment subrectangular; telson triangular and shorter than the sixth segment. Female abdomen (Fig. 3C) naked, covered sternum; all segment separated.

First pleopod of the male (Fig. 3D, E) curved ventrally and serrated along the margins. Second gonopod small, short, ex-

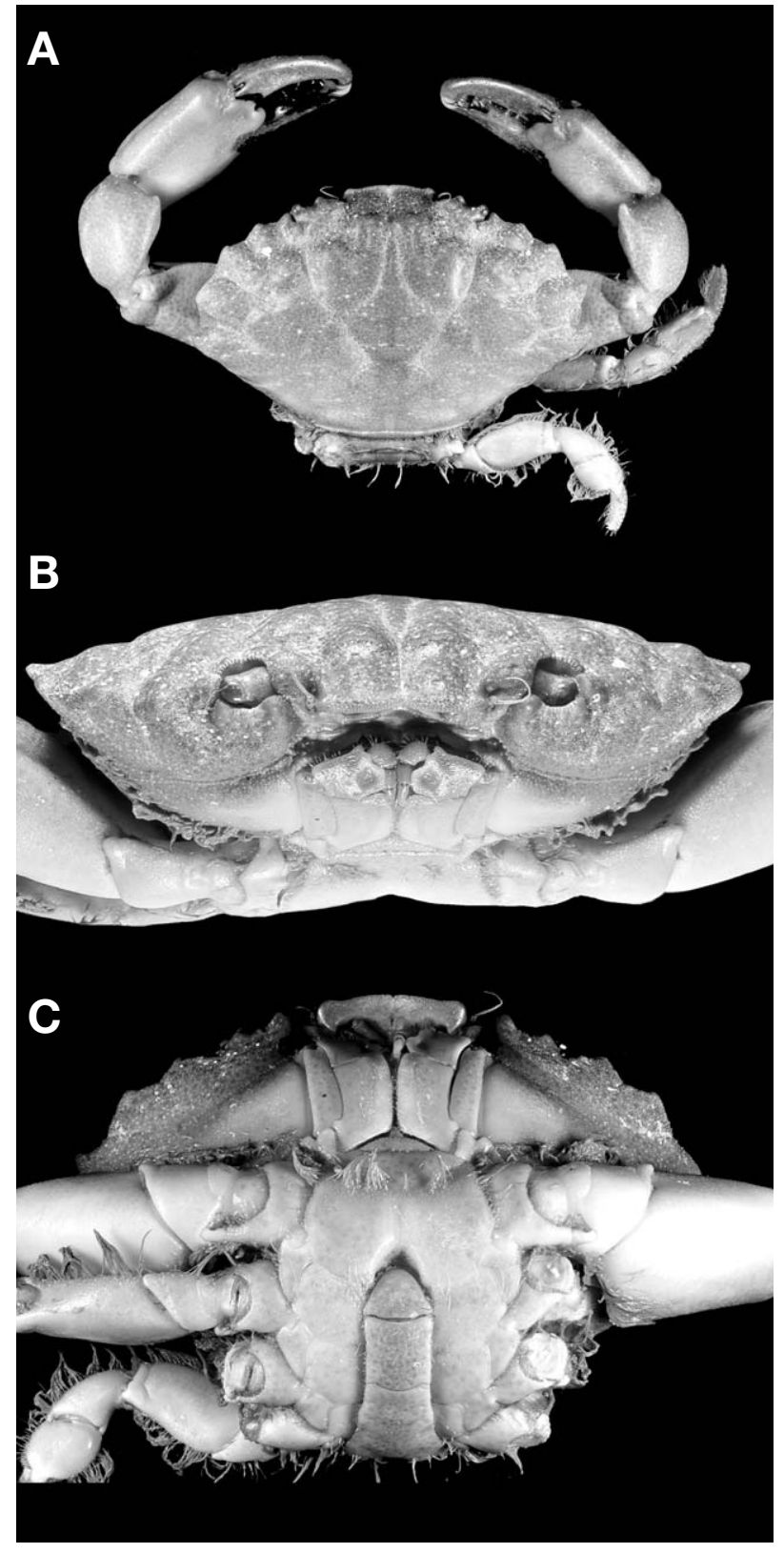

Fig. 1. Etisus laevimanus Randall, 1840, male (cl $28.3 \mathrm{~mm}$, cw $44.8 \mathrm{~mm}$ ). A, Whole animal, dorsal view; B, Anterior view; C, Ventral view. $\mathrm{Cl}$, carapace length from the front to the posterior dorsal margin of the carapace; cw, with of the carapace measured at the widest part.

tending about $1 / 4$ length of first gonopod, slightly swollen terminal bulb narrowing to sharp spine.

Habitat. Crevices of rocks or under stones, intertidal zone. Distribution. China, Hawaii, India, Japan, Singapore, Tai-

Korean name: ${ }^{1 *}$ 민돋음부채게 (신칭) 


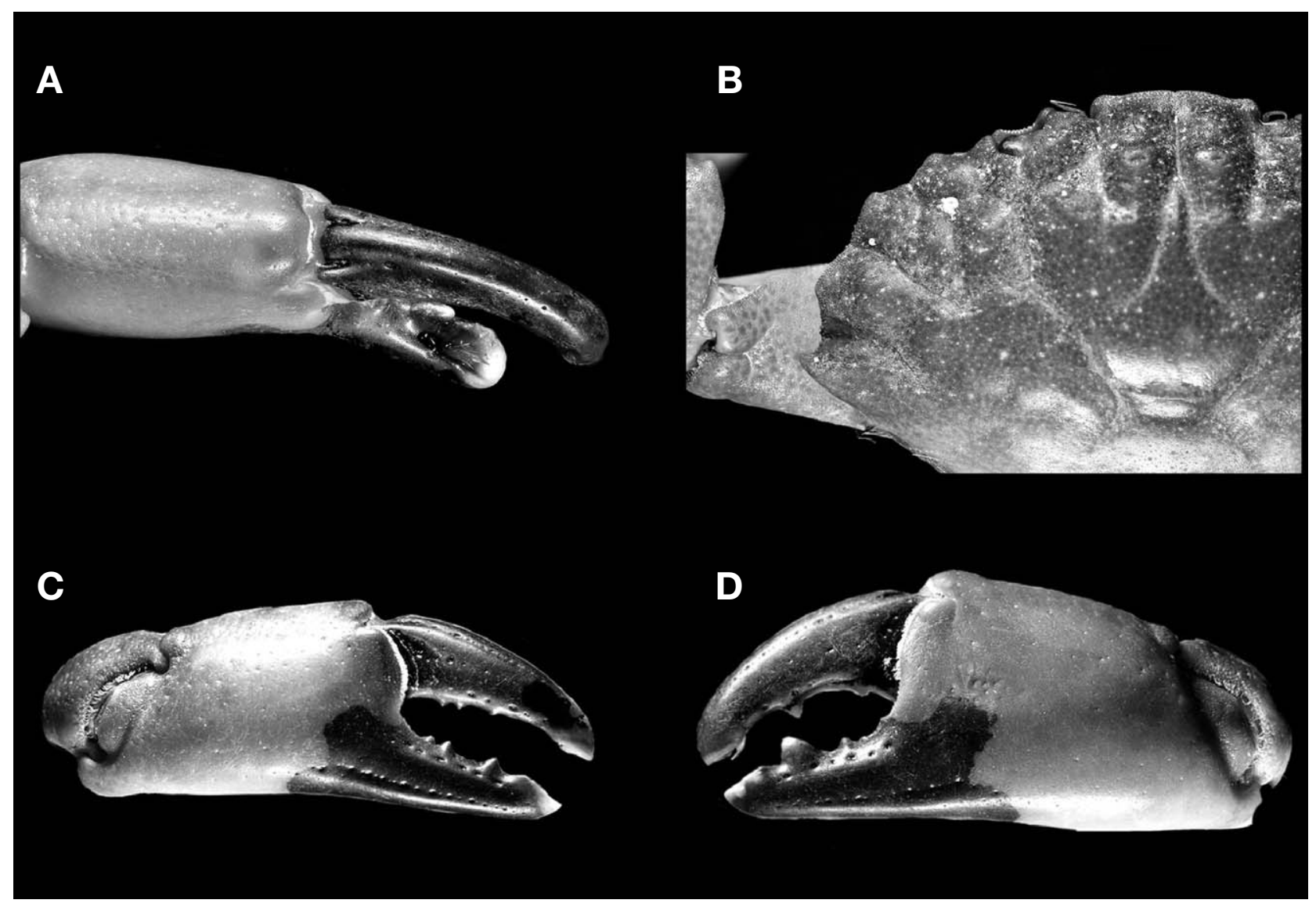

Fig. 2. Etisus laevimanus, male ( $\mathrm{cl} 28.3 \mathrm{~mm}, \mathrm{cw} 44.8 \mathrm{~mm}$ ). A, Left cheliped, dorsal view; B, Anterolateral border, dorsal view; C, Right cheliped, outer view; D, Left cheliped, outer view. $\mathrm{Cl}$, carapace length from the front to the posterior dorsal margin of the carapace; $\mathrm{cw}$, with of the carapace measured at the widest part.

wan, east-southern coast of Africa, and Korea (the present study).

Remarks. In Korea, Etisus anaglyptus H. Milne Edwards, 1834 was only reported in genus Etisus $\mathrm{H}$. Milne Edwards, 1834, and was collected from Uljin, Korea. Etisus anaglyptus bears four or five tubercles on the upper surface of propodi of chelipeds, 4 tubercles on anterolateral border, and the narrow frontal width. However, E. laevimanus, the second species reported in the genus from Korea, has smooth upper surface of propodi of chelipeds, 4 broad and triangular teeth on the anterolateral border, and relatively broader frontal width. The Korean specimens agreed with the description of E. laevimanus by Dai and Yang (1991), and they were collected from same habitat of E. anaglyptus collected previously in Korea.

Etisus laevimanus occurs in Hainan Island and Paracel Island of China, Taiwan, and from Okinawa to Sagami bay of Japan. In Korea, this species only appears in Uljin of the East Sea. Two species of the genus Etisus, E. anaglyptus and E. laevimanus, have only occurred from Uljin in Korea. It means that Koran two species of Etisus has not appeared in the Yellow sea.

${ }^{1 *}$ Genus Paraxanthias Odhner, 1925

${ }^{2 *}$ Paraxanthias elegans (Stimpson, 1858) (Figs. 4, 5)

Xanthodes elegans Stimpson, 1858: 33; 1907: 47, Pl. 5, fig. 3.

Xanthias atromanus Haswell, 1882: 49.

Paraxanthias elegans: Sakai, 1976: 430, fig. 226, Pl. 155, fig.

2; Dai and Yang, 1991: 300, fig. 156B(3), Pl. 38(5).

Xanthias elegans: Serène, 1984: 191 (key), 194 (key).

Material examined. Korea: $1 \sigma^{7}(\mathrm{cl} 8.8 \mathrm{~mm}, \mathrm{cw} 13 \mathrm{~mm})$, Gyeongsangbuk-do, Uljin-gun, Jukbyeon-myeon, Hujeong-

Korean name: ${ }^{1 *}$ 예쁜부채게 속(신칭), ${ }^{2 *}$ 예쁜부채게 (신칭) 

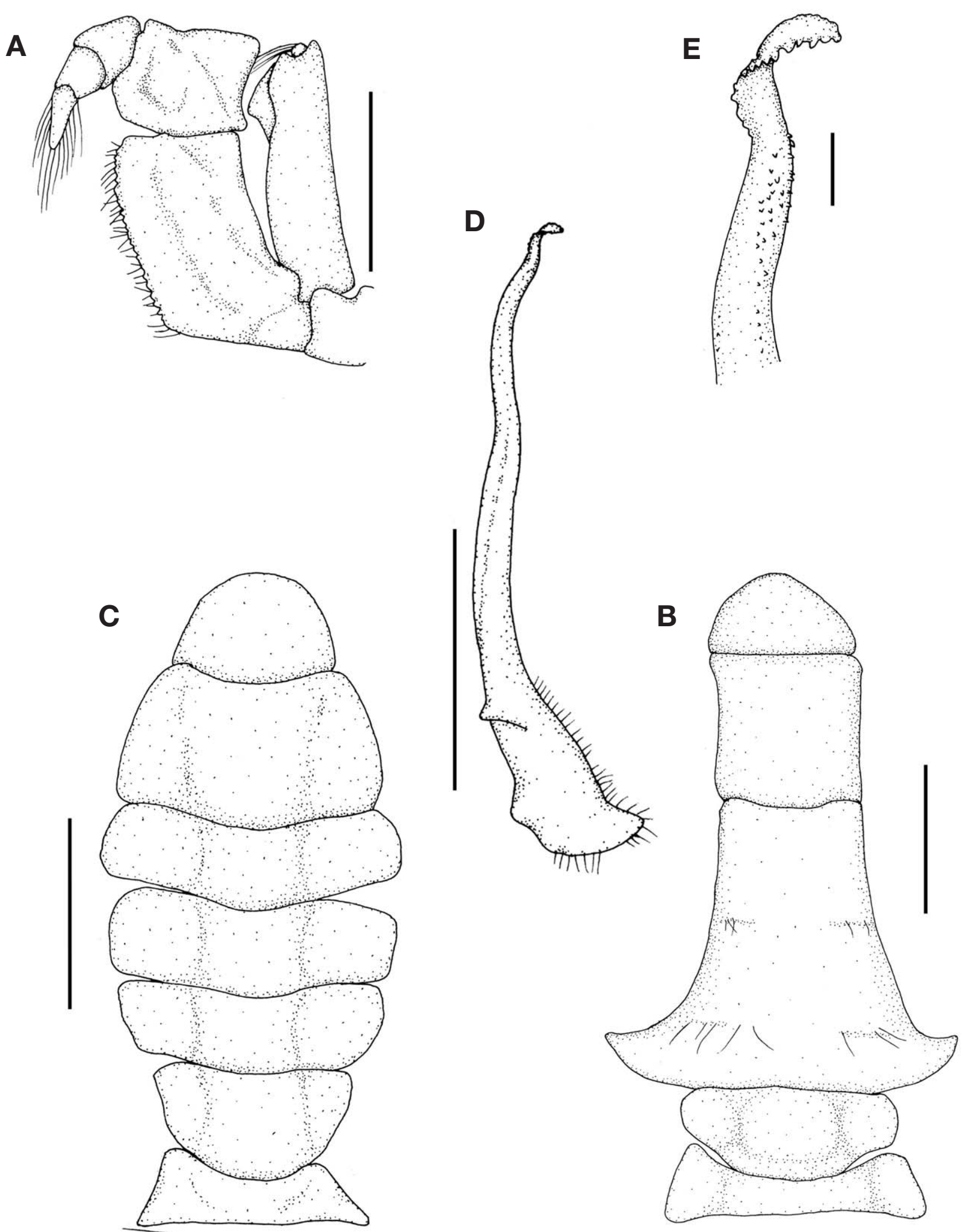

Fig. 3. Etisus laevimanus. A, Left third maxilliped; B, Male abdomen; C, Female abdomen; D, Left male first gonopod, ventral view; $E$, Tip of left male first gonopod, ventral view. Scale bars: $A-D=5 \mathrm{~mm}, E=0.5 \mathrm{~mm}$. 

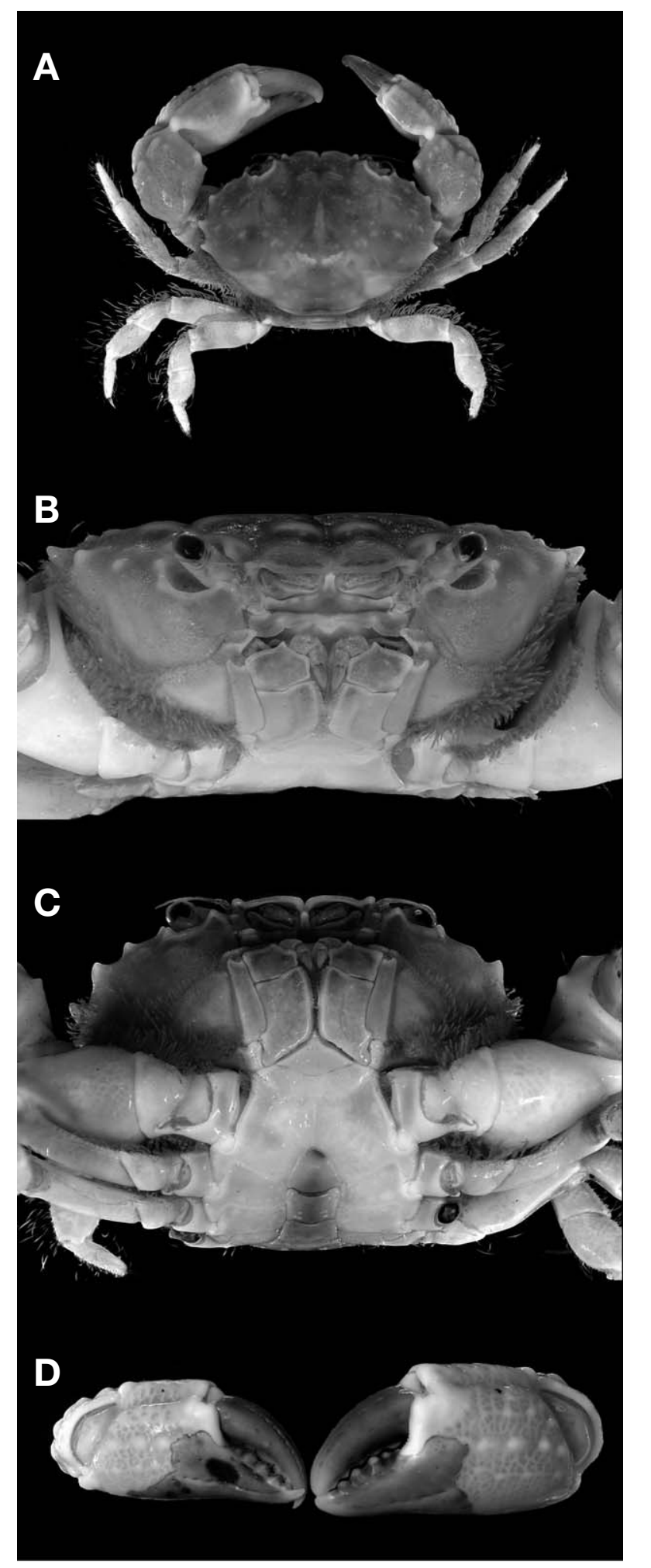

Fig. 4. Paraxanthias elegans Stimpson, 1858 , male (cl $8.8 \mathrm{~mm}$, cw $13 \mathrm{~mm}$ ). A, Whole animal, dorsal view; B, Anterior view; C, Ventral view; D, Chelipeds, outer view. Cl, carapace length from the front to the posterior dorsal margin of the carapace; cw, with of the carapace measured at the widest part.

\section{ri, 27 Sep 2012, SCUBA diving, Col. Rho HS.}

Description. Carapace (Fig. 4A) transversely oval, being weakly convex anteriorly; dorsal surface naked, and well divided into areolae by shallow, with short ridge on each of $1 \mathrm{M}, 2 \mathrm{M}, 3 \mathrm{~L}$, and $4 \mathrm{~L}$ lobes; covered with thick microscopical granules, being not convex. Front (Fig. 4A-C) deflected downwards, convex near median notch but concave near outer side, separated from inner orbital angle by notch. Antennal basal segment rather wide but short; its inner angle just touched with the short ventral prolongation of the front; outer angle raised to level of inner infraorbital angle; antennal flagellum rather stout and only slightly longer than the major diameter of the orbit, being provided with microscopical secondary. Anterolateral border (Fig. 4A) with 4 obtuse teeth beside outer orbital tooth, last two later and more produced. Posterolateral border somewhat, directed downwards, and as wide as front. Ischium of third maxilliped (Figs. 4B, $\mathrm{C}, 5 \mathrm{~A}$ ) bearing angle at anterior-lateral region.

Chelipeds (Fig. 4A, D) stout, asymmetrical. Merus smooth with its outer surface; inner surface concave; anterior margin granulate. Carpus sculpturesque with outer surface; upper surface dentiform, and with 2 teeth at inner-distal angle. Propodus smooth on surface except for dorsal surface; dorsal surface situated longitudinal groove along outer border; upper-outer surface furnished with large tubercles arranged in rows, forming irregular crests; dactylus stout, with teeth on cutting edges; immovable finger of minor chelipeds with distinct longitudinal groove along the middle of the outer surface.

Ambulatory legs (Fig. 4A) comparatively stout. Merus naked on both surface, with hairs and row of conical granules on upper border. Carpus, propodus and dactylus are densely covered with several long hairs. Upper borders and surfaces carpus and propodus armed with rather sparse conical granules. Upper surface of the carpus with longitudinal row. Dactylus much narrower than propodus, armed also with several sharp, more or less elongate granules on upper surface and with thick yellow, semitransparent spinules on upper border near terminal claw.

Male abdomen (Figs. 4C, 5B) with third to fifth segments fused; sixth segment square, broader than long; telson with distal margin coniform.

First gonopod (Fig. 5C-E) with distal portion curved laterally, finger-shaped at tip and armed with long feathery hairs on inner side.

Habitat. Rocky or pebbly beach, under stones or in crevices of rocks.

Distribution. Australia, China, Japan, Taiwan, and Korea (the present study).

Remarks. The characteristics of the examined specimen agreed well with the description of Dai and Yang (1991) ex- 

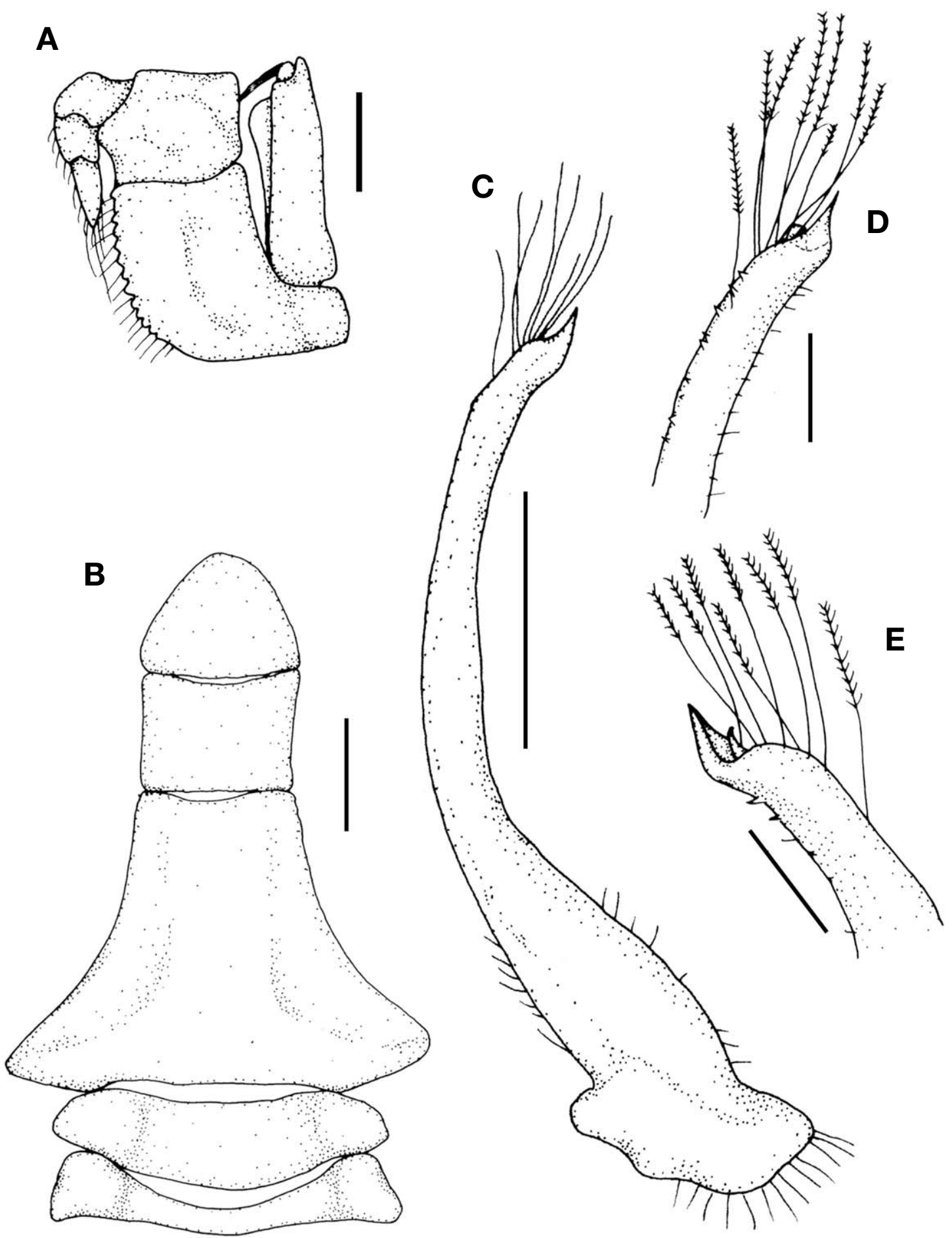

Fig. 5. Paraxanthias elegans. A, Left third maxilliped; $B$, Male abdomen; $C$, Left male first gonopod, ventral view; $D$, Tip of left male first gonopod, ventral view; $E$, Tip of left male first gonopod, dorsal view. Scale bars: $A-C=1 \mathrm{~mm}, D, E=0.3 \mathrm{~mm}$.

cept for the male first gonopod. The examined specimen showed 8 feathery hairs on the tip of the first gonopod while the description of Paraxanthias elegans of Dai and Yang
(1991) referred to 5 feathery hairs (see Dai and Yang, 1991: fig. 156B). 


\section{ACKNOWLEDGMENTS}

This work was also in part with the support through the research program of KIOST with contract No. PE99202 and PE 99204.

\section{REFERENCES}

Dai A, Yang S, 1991. Crabs of the China seas. China Ocean Press, Beijing, pp. 1-608.

Dana JD, 1853. On the classification and geographical distribution of Crustacea. In: Report on Crustacea of the United States Exploring Expedition, under Captain Charles Wilkes, U.S.N., during the years 1838-42. C. Sherman, Philadelphia, pp. 1395-1592.

Forest J, Guinot D, 1961. Crustacés Déca-podes Brachyoures de Tahiti et des Tuamotu. In: Expédition française sur les récifs coralliens de la Nouvelle Calédonie. A, Lahure, Paris, pp. 1-195.

Haswell WA, 1882. Catalogue of the Australian stalk- and sessile-eyed Crustacea. The Australian Museum, Sydney, pp. 1-324.

Holthuis LB, 1953. Enumeration of the Decapod and Stomatopod Crustacea from Pacific Coral Islands. Atoll Research Bulletin, 24:1-66.

Lee SK, Shin MH, Park TS, Kim W, 2012. New report of three xanthid crabs (Crustacea: Decapoda: Xanthidae) from Korea. Animal Systematics, Evolution and Diversity, 28:117-125.

Ng PKL, Guinot D, Davie PJF, 2008. Systema Brachyurorum: Part I. An annotated checklist of extant brachyuran crabs of the world. The Raffles Bulletin of Zoology, Supplement, 17: 1-286.

Randall JW, 1840. Catalogue of the Crustacea brought by Thomas Nuttall and J. K. Townsend, from the west coast of North America and the Sandwich Islands, with descriptions of such species as are apparently new, among which are included several species of different localities, previously existing in the collection of the Academy. Journal of the Academy of Natural Sciences of Philadelphia, 8:106-147.

Sakai T, 1976. Crabs of Japan and the adjacent seas. Kodansha Ltd., Tokyo, pp. 1-773.

Serène R, 1984. Crustacés Décapodes Brachyoures de l'Océan Indien occidental et de la Mer Rouge, Xanthoidea: Xanthidae et Trapeziidae. Avec un addendum par Crosnier, A: Carpiliidae et Menippidae. Faune Tropicale, 24:1-349.

Stimpson W, 1858. Prodromus descriptionis animalium evertebratorum, quae in Expeditione ad Oceanum Pacificum Septentrionalem, a Republica Federata missa, Cadwaladaro Ringgold et Johanne Rodgers ducibus, observavit et descripsit. Pars IV. Crustacea Cancroidea et Corystoidea. Proceedings of the Academy of Natural Sciences of Philadelphia, 10:31-40.

Stimpson W, 1907. Report on the Crustacea (Brachyura and Anomura) collected by the North Pacific Exploring Expedition, 1853-1856. Smithsonian Miscellaneous Collections, Washington, 49:1-240.

Received August 19, 2014 Revised September 16, 2014 Accepted September 22, 2014 